Holdsworth, C. and Brewis, G. (2014) Volunteering, choice and control: a case study of higher education student volunteering .Journal of Youth Studies 17(2), 204-219

\title{
Abstract
}

There has been a step change around youth volunteering in the UK in recent years as this once unheralded and taken for granted activity has moved more centre stage, particularly as a key strand of recent Government initiatives directed towards welfare reform, employment and education policies. This article uses the case study of student volunteering to explore the paradox inherent in articulations of volunteering in policy discourses that emphasise self- responsibility for employability and community cohesion. We review the tensions inherent in escalating the expectation that young people should volunteer through situating volunteering as a conduit of control society, and consider how the promotion of participation destabilizes the capacity for sovereign action and choice. Drawing on qualitative research with both HE stakeholders and students, we map out the external policy drivers that universities are reacting to in promoting volunteering, and students' response to these initiatives. Our analysis demonstrates that students resist the expectation that they should volunteer if this is interpreted as devaluing their engagement. Both students and stakeholders recognise that the promotion of volunteering should seek to align institutional practices to promote and support volunteering with young people's own expectations and aspirations.

Key words: Volunteering, Higher Education Policy, Choice, Control Society 


\section{Volunteering, choice and control: A case study of Higher Education student volunteering}

\section{Introduction}

Volunteering has come under the public spotlight in recent years. In the UK, for example, from the popular celebrations of Olympic volunteers to political support for volunteering as part of the 'Big Society'; the figure of the selfless volunteer has been reinterpreted as a key social actor who can bridge community needs with individual reward and recognition. The social and individual transformatory potential of volunteering has been stressed in the context of youth transitions, and the opportunities for young people to develop skills and enhance employability profiles, while contributing to the 'social good', are mostly unchallenged. The ideal of active citizenship assumes that volunteering is a choice, and the celebrated figure of the selfless volunteer who contributes to their communities is valued not just on the basis of his/her unique contribution, but because their contribution is given willingly without compulsion. Yet the popular and political endorsement of volunteering is not straightforward. In this article we consider if the current push for young people to volunteer and the belief that they will benefit from doing so, may undermine the voluntary nature of these activities. Are we effectively introducing obligatory forms of volunteering for which young people's individual choices and forms of engagement are subsumed by a wider narrative that emphasises the benefits of participation and the potential loss in terms of skills, employability and personal worth of not getting involved? But can, and should we, enfranchise this quintessentially unique and personal activity? Put simply if everyone volunteers, or at least feels that they have to, what does this mean for the activity of volunteering itself? 
We address these questions with reference to the case study of student volunteering in the UK and consider how the contradiction between coercion and choice are intrinsic to the embedding of volunteering in Higher Education (HE). ${ }^{1}$ Our analysis of the drive towards more directed volunteering considers how through volunteering individuals become 'institutionally and discursively situated' (Baillie Smith and Laurie , 2011: 556). We are therefore resisting more conventional interpretations of volunteering that envisage it as a manifestation of personal choice to give time, advice or support. This is established in volunteering literature by a preoccupation with defining and interpreting individual motivations (see for example Hustinx et al, 2010; Hwang et al, 2005 and Rehberg, 2005). Analyses of volunteering motivations have sought to map individual orientations to wider social processes, and to discern a shift from altruistic to self-interested motivations that can be explained with reference to the logic of individualisation in advanced economies (Hustinx, 2001; Hustinx and Lammertyn, 2003). Our contention is that the co-opting of voluntary action into institutional HE practice, and how students respond to this, cannot just be interpreted through the lens of individualisation. Rather we suggest that the emergence of a new pact between students and universities to promote and facilitate volunteering is emblematic of what Deleuze discerns as the shift from disciplinary to control society (1992). Deleuze's exploration of control takes as its inception Foucault's disciplinary society, to consider how the authority that was once invested in institutions is integrated into everyday life by increasingly interconnected networks. In the case of student volunteering we consider how the co-option of activities such as volunteering into HE practice is redefining the relationship between students and Higher Education Institutions (HEls), as well as

\footnotetext{
${ }^{1}$ This paper considers student volunteering, these can include activities that students acquire credits for, but not those that are formally required as part of their studies such as placements. We recognise that similar arguments can apply to more formalised experiences, but we do not have space in this paper to consider the totality of student engagement and work experience.
} 
aligning students' orientation towards volunteering with policy initiatives that emphasise students' self- responsibility for employability and community cohesion.

In the following sections we review how the landscape of HE volunteering in the UK is shaped by contradictory neo-liberal discourses and then turn to consider how the theorisation of control society provides a conceptual framework to reveal these contradictions. Drawing on research with both stakeholders at universities and students who identify themselves as volunteers and non-volunteers, we consider how universities are setting the agenda for student volunteering and in turn how students articulate their expectations about and experiences of volunteering in the context of intensive promotion, both within institutions and externally, of volunteering and its benefits.

\section{Redefining volunteering and student engagement}

Student volunteering at university has probably never been so popular, or at least been so visible. In the UK, while students have a well-established tradition of contributing to communities where they study, this has for most of the 20th century been unheralded and not seen as central to the university mission compared to research or teaching activities (Brewis, 2010). Thus the development of volunteering initiatives has been uneven and support for volunteering in UK universities is varied, ranging from student-led activities, including social enterprise initiatives, to university-run volunteering bureaux (Darwen and Rannard, 2011; Squirrell, 2009). The diverse institutional support for HE volunteering is indicative of the different conceptualisations of volunteering that have dominated student volunteering at particular historical times, and the current push towards more directional engagement can be contrasted with student-led community action of the 1960s and 1970s (Brewis, 2010). The development of student volunteering in the UK illustrates how these 
activities are embedded in institutional and cultural contexts. It is germane therefore to consider more recent political, economic and cultural triggers that are shaping current volunteering initiatives in $\mathrm{HE}$.

All forms of volunteering have come under intense political and social inspection in recent years, reflecting the significance of political reform that is redrawing the boundaries of the welfare state and wider social concerns about the breakdown of community (Fyfe, 2005; Kendall, 2000; Smith, 2010). The issue of how to promote civil society has considerable political heritage (Jochum et al, 2005) and successive governments have introduced initiatives to promote civil renewal. As part of this, the voluntary sector is subject to enhanced scrutiny in how it responds to a recasting of the welfare state that envisages a withdrawal of formal state support and increasing capacity of third sector organisations to deliver welfare functions, while at the same time connecting individuals within communities to develop models and practices of active citizenship. This renewed interest in the functionality of the voluntary sector is generating considerable academic interest in how the sector is responding, yet to date literature on volunteers themselves is more sporadic (see Kendall, 2003 and Milligan and Conradson, 2006; Mohan, 2012). There is an important theoretical and empirical gap in our understanding of what is proposed for the voluntary sector and how individuals themselves will meet this need. The current UK government's initiative around the 'Big Society' for example, relies on individuals both to engage with the project itself and to acquiesce with the active model of citizenship that is proposed (Cabinet Office, 2010; Norman 2011). The political rhetoric that seeks to link rights with responsibilities charges individuals with the need to ensure not just their own wellbeing, but that of their communities. Yet as Miller (2000) observes the model of citizenship espoused 
by political activists on both left and right, that of the individual with rights and actively involved in their communities, is not one that is recognised by the majority of people in contemporary British society. Aligning engagement with rights not only challenges the basis on which many people participate, but also creates a moral imperative to volunteer. For example Brooks (2012) considers how the UK Coalition Government conceptualisation of youth citizenship recasts young people as 'dutiful' through schemes such as the National Citizen Service, rather than as agents of change.

Yet it is not just a recasting of volunteering through policy initiatives such as the Big Society and the National Citizen Service that is shaping volunteering in universities, and there are parallels between the neo-liberalisation of welfare that is rooted in the Big Society agenda with recent reforms of the HE sector. The transfer of the financing of HE from central government tax revenue to individual students paying higher fees, harnesses student choice as the calibrator of the university market (Collini, 2012; Rice, 2011). This marketization is transforming the relationship between students and universities and echoes the model of individual responsibility assumed in Big Society narratives. Though, as Larner (2009) argues, we need to be careful about making sweeping statements about 'the' project of neoliberalism as if it is a cohesive whole that manifestly transforms institutions and our engagement with them. Rather she suggests that 'theorising neoliberalism as an assemblage allows apparent "paradoxes" and "ironies" to become integral aspects of our analyses, rather than inconvenient tensions to be overlooked or pushed to one side' (Larner, 2009: 1577). In the context of $\mathrm{HE}$, the neoliberal agenda is creating a very real tension between students as informed consumers able to articulate choice and their status as leaners which is configured through their engagement with institutional practice. Responding to students' 
expectations and demands is not necessarily conducive to delivering high quality education. For volunteering this contradiction emerges around the notions of choice and service (Boyer, 1990; Edwards et al, 2001; Mohan, 1994). Volunteering is championed for its ability to seamlessly bind together individual preparation for work practices and cultures (Jones, 2011) yet at the same time transforming individuals and communities (Eley, 2003). Thus through volunteering individuals are called upon to directly fill the service gaps exposed by the withdrawal of state support, but in the context of HE this activity simultaneously contributes to students' learning and employability.

At one level the promotion of volunteering and employability is unproblematic; it appears almost self-evident that students will gain an advantage in the labour market through their involvement in activities outside of their studies, with the added benefit of 'doing good'. While volunteering as preparation for paid employment might be a rational decision (Jones, 2011), the expectation that it can infer advantage for those who take part is more contentious. As Brown et al (2003) argue employability is both absolute and relative, students at university need to acquire transferable skills in preparation for graduate employment, but at the same time need to be able to compete with their peers in an evertightening job market. The emphasis on employability places the responsibility of securing a graduate job on students themselves rather than on external structural factors, such as the conditions of the labour market and the enhanced global competition for graduate employment (Brown et al, 2010). Employability is, therefore, a project of the self. Underlying this project is the drive for 'distinction' through activities such as volunteering, as students need to be able to 'stand out from the crowd'. Yet contradictions emerge when these distinctive activities are embedded in institutional practice, as the skills and attributes 
that students acquire do not provide a relative advantage if all students are encouraged to participate. It is important therefore to query the logic of aligning the promotion of volunteering through employability discourses.

Volunteering, Choice and Control Society

Directional volunteering in HEls can usefully be understood as incorporating two competing trends that are shaping youth transitions: on the one hand there is an emphasis on the negation of risk and the commodification of experience yet at the same time young people are encouraged to embrace a postmodern celebration of difference and individualism (Lash and Urry, 1994). As Ansell (2008) elaborates this tension between negating risk and celebrating difference is particularly pertinent for volunteering schemes that are spatially constituted such as gap year travel and volunteer tourism. The recent rapid expansion of service industries to provide risk-averse but at the same time 'unique' experiences is indicative of a shift towards more sanitised and mediated experience, though one that Ansell suggests is not indicative of 'totalising control' (2008: 237).

This tension between risk and control is relevant to more localised forms of engagement. University-directed volunteering opportunities fall short of being obligatory or required though the promotion of these activities can be seen as subverting the force of creativity, turning the desire for creativity on itself by requiring students to 'be' distinctive. The locus of control does not therefore rest in the institution and how the university overtly directs student action but how this is realised through embodied engagement. The changing relationship between university and student can be interpreted with reference to the shift from disciplinary to control society (Deleuze, 1992). It is Deleuze's interpretation of 
Foucault's writings on discipline (1979) that alerts us to the transfer of the locus of power from disciplinary institutions to more fluid and democratic forms that are operated through 'the brains and bodies of the citizens' (Hardt and Negri, 2000:23). In disciplinary society discipline operates in more confined spaces and institutions, and for HE is bound up with the regulation of academic instruction and certification. Yet the shift to control society brings about a dissipation of power in which authority is no longer confined to institutions . . As Hardt and Negri suggest this is associated with the constant and perpetual process of control and regulation::

The society of control might thus be characterised by an intensification and generalisation of the normalising apparatuses of disciplinarity that internally animate our common and daily practices, but in contrast to discipline, this control extends well outside the structured sites of social institutions through flexible and fluctuating networks (2000: 23).

In using the distinction between discipline and control our intention is not to set up an opposition between Foucault and Deleuze that maps on to a stark distinction between discipline and control. Rather our interest is the nexus of the shift from discipline to control and how this revolves around a subtle, though revealing, rescripting of the relationship between the individual and the institution.

Delueze recognises, though very briefly, how the restructuring of education is caught up with the dissipation of power and the porosity of institutional authority. He reflects how many young people 'strangely boast of being-motivated; they re-request apprenticeships and permanent training' (1992: 7). Thus instruction and training are no longer the sole domain of institutions but have become projects of the self that are rolled out through the 
blurring of distinctions between educational practice and everyday life. The perpetuation of training and skills acquisition in control society depends on those engaged in these activities believing that they can be masters of their own fate through their own diligence. Yet in seeking to take responsibility for their own education and employment outcomes, young people are also being co-opted into the project of employability. It is this alignment of individual aspiration and institutional direction that is a cornerstone of control, as Watson (2010: 96) suggests 'control happens when our own desires appear to align with, but in fact emanate from, the interests of the state (or whatever institution it is that desires our desire).' In universities, traditional concerns with teaching and learning and been supplanted by embracing the totality of the 'student experience'. Volunteering, along with other activities that were once termed 'extra-curricular' have become instructional, and are co-opted into the domain of HE as 'co-curricular' activities. It is germane to consider therefore how universities are aligning support services for volunteering in response to external policy drivers and in turn how students' volunteering experiences are shaped by discursive and institutional practices.

\section{Methodology}

We use data collected in 2010 from a project run in collaboration with the Institute for Volunteering Research and funded by the National Coordinating Centre for Public Engagement. This project included case studies of six HEls selected to represent the diversity of the HE sector in England and the organisational structure of volunteering support services. These include one of the oldest universities in the country and one of the most recently established and comprise of three pre-1992 universities and three post-1992 
universities. ${ }^{2}$ The HEls selected broadly reflect the most common structures of coordinating student volunteering, including brokerage services located in Employability or Community Engagement departments and/or students' unions, vinspired programmes, volunteering modules/electives, student-led volunteering societies and student-led social enterprise. ${ }^{3}$ The research design used mixed methods, incorporating an online survey and two interrelated strands of qualitative data collection: peer-led case studies comprising of focus groups and mapping exercises and researcher-led in-depth case studies. These in-depth case studies comprised 12 in-depth biographical interviews with student volunteers, 15 semistructured interviews with representatives of volunteer-involving organisations and ten semi-structured interviews with university stakeholders including academics, Pro-ViceChancellors and university or students' union-based volunteer coordinators. The analysis presented here is based on analysis of the focus groups with volunteers and non-volunteers, biographical interviews with student volunteers and the interviews with stakeholders. The interviews and focus groups with student (non)volunteers were carried out to record student experiences of volunteering and perceived barriers to getting involved. The interviews with stakeholders were carried out at the same time as the research with students, in order to record how university policy and services were responding to both students' and community organisations requirements for volunteering opportunities and $\mathrm{HE}$ policy initiatives. All interviews were analysed thematically and the results presented here focus on both students' and stakeholders discussions of overt and more subtle initiatives to promote student volunteering.

\footnotetext{
${ }^{2}$ Post-1992 HEls are former polytechnics that were conferred the status of university by the Further and Higher Education Act of 1992. These institutions are more closely associated with delivering vocational courses rather than the research focus on pre-1992 HEls, though this distinction is becoming less applicable.

${ }^{3}$ The charity vinspired is a government-sponsored charity that provides volunteering opportunities for young people, some of which have been made available through HEIs.
} 
Though we are not presenting detailed analysis of the survey it is noteworthy that the survey analysis established that the majority of student respondents (63 per cent) reported some form of involvement with volunteering, and this rate is comparable to that found in other cross-national surveys (Handy et al, 2010). It is also important to dispel some common assumptions about student volunteering. In particular, analysis of the survey revealed that there is no trade-off between paid work and voluntary work and volunteering is not necessarily favoured by students from more privileged backgrounds. Rather, volunteering is taken up across the student corpus, though the type of institution is significant for volunteering activity (Brewis et al, 2010).

Institutional Support for Student Volunteering

The need for institutional support for student volunteering was a common theme in all stakeholder interviews. There is recognition that a laissez-faire approach in which volunteering was organised primarily by students themselves, was less appropriate given important changes to both university finances and the social and political context of $\mathrm{HE}$, particularly the expansion of the 'skills' agenda (Haski-Leventhal, 2009). As one senior HE manager described, support for volunteering at universities needs to make more explicit synergies between volunteering and academic studies:

So that they obviously gain all kinds of skills from their academic work, and they gain all kinds of complementary skills from their co-curricular activity. And we put those two together, we try and encourage students to keep those two things together in their heads rather than seeing 'extra-curricular' which is a term we don't use, as being something as an add on. But in that co-curricular space, volunteering is clearly 
one of the key opportunities that we want to give students and that we want to maintain the opportunity to give to students. So you know, that's just a way of saying in a long winded that it's core in terms of the way we see the quality of the student experience. [Pro-VC pre-1992 HEI]

The shift from 'extra' to 'co' curricular is perceived as more than a rebranding of traditional student activities but is explicitly encouraging students themselves to develop synergies across their university experiences and activities and to join these together in fulfilling the requirement to articulate subjectivity. Yet as another senior HE manager observed, this shift of emphasis towards integrating volunteering within HE is not something that has been brought about by a changing emphasis within the university, but by external drivers:

So there is that external policy drivers, and the various sort of papers that have been released. To me, and it's probably because I come from a health background, there is a need for us to actually work with students to develop them in a range of attributes, in order to prepare them to be a good citizen. I mean it's very cliché but that's part and parcel. This isn't about just their academic attainment, it's about developing the additional skills, both within the academic programme and also outside. [Pro-VC, Post-92 HEI]

The importance of external drivers reflects the increasing market position of HE within the English education system, and in the case of volunteering this is made explicit with reference to employability. As one Pro-Vice-Chancellor explained the 'old-fashioned' view of a good education was no longer sufficient, and both universities and students need to recognise their joint responsibilities in enhancing employability: 
[W]ell it's to do, it's a lot to do with employability, it's a lot to do with our sense that it's increasingly our responsibility to be much more overtly responsible for students making themselves as employable as possible than you know an institution like this used to think of itself as being, do you know what I mean, we used to think of ourselves as just being like, oh they'd all get jobs because they'd had a good academic education and that kind of old fashioned view. [Pro-VC pre-1992 HEI]

Thus while employability places the emphasis on students' ability to sell their human and personal capital (Brown et al, 2003), their capacity to do so is increasingly recognised as falling under the remit of universities' responsibilities. Moreover universities are scrutinised in how effectively they meet their obligations of enhancing student employability. Thus while the discourses of employability charge students with the responsibility for ensuring their own success in the graduate labour market, universities will also be held to account in how students are supported in articulating their skills and attributes. One way in which universities are responding to this is through explicitly recording students' co-curricular activities. In the UK this is materialised in the form of the Higher Education Achievement Report [HEAR] (Hefce, no date) which was rolled out for all students graduating in 2012 from English universities. This report provides students with a detailed academic transcript and a record of other endorsed activities. The HEAR extends earlier concerns with 'graduateness' that identified a core set of qualities to distinguish someone who has undertaken a degree, in that it provides an individualised record of students' attributes and achievements (Glover et al, 2002). The report will facilitate comparisons between student experiences, rather than confirming a core set of activities. The HEAR can be viewed as a technology of control in that all students will have this transcript, yet it is down to each 
student to ensure that it is a detailed and full as possible. Thus, as one volunteering manager described, the HEAR could provide a way of mainstreaming volunteering activities:

And the reason I'm quite excited about HEAR is because it is a template that everyone will be using, so it feels like that will be a way. And I think if it does get implemented and everyone's using it, I think it will really, it will be a great tool for people letting us know what they're doing already, but I also think it will be a motivator for people who aren't doing things, again depending how much it's marketed and spoken about, but if, which is what they're talking about, if they're saying you will get this at the end, and if you haven't done anything extra-curricular this section will be blank, then you know people might think about doing some other stuff! [Volunteering manger Post-92 HEI]

Yet the assumption that universities can generate a cultural shift in volunteering purely in response to external drivers that support the transparency and recording of extra-curricular activities is too simplistic, as some stakeholders recognise. The responsibility of universities is to translate policy drivers so that students have the capacity to reflect on their civic and individual responsibilities:

So it's a kind of, it also is a way of treating them as I think, I hope, again more kind of mature and responsible citizens who kind of take up the opportunities, and it's our responsibility to make sure they know they're there you know, and then to reflect on them appropriately, to everybody's benefit. So that's the way it works, that's the theory. [Pro-VC pre-1992 HEI]. 
However the observation that universities share in students' learning about citizenship and responsibility is not one that has been traditionally central to HE ethos in the UK (Annette, 2005). As one Pro-Vice-Chancellor remarked, the theory is that by providing volunteering opportunities this will engender students' awareness of their responsibilities, yet in practice there is less evidence of how this may be achieved (Kahne and Westheimer, 2006).

Initiatives for recording volunteering activity and celebrating individual achievement provide a practical way of linking volunteering with employability, though learning about social responsibility is treated as more serendipitous. Moreover for this vision to be effective it will rely on universities recognising their responsibilities to local communities as well as students (see Boyer, 1990; Marullo and Edwards, 2000).

At a time of rapid change in the HE sector in England it would be unreasonable to expect practice and discourse to move at the same pace. Stakeholders at universities are keen to articulate the need for universities to support volunteering, and acknowledge that this is in response to external drivers, rather than student demand or requests from local communities. This new vision for volunteering depends on all parties, HE managers, academics and students, to acquiesce with the role of volunteering in $\mathrm{HE}$ and to recognise its benefits. Universities can provide structures to stimulate and recognise volunteering, yet this does not imply that volunteering will become obligatory. In contrast, as one Pro-ViceChancellor remarked, preserving student choice is an essential part of university mandates, along with supporting employability, and that a shift, whether actual or perceived, towards obligatory or mandatory forms would backfire:

And I think what we do have to recognise is that from the age of eighteen, students are adults and I think we do have to recognise that they have choice and they can 
choose to engage or not to engage. The other parallel to be drawn there is the fact that by compelling students to do this, if the student doesn't have the skills or perhaps is very reluctant, what you then are actually doing is creating a problem in the environment that you're actually putting them in to volunteer, and that then creates bad you know sort of relationships between this institution and the community environment. So what you would want is for the experience, for the student to be wanting it and it to be a success out there, and I think compulsion probably would actually lead to an awful lot of problem that you'd spend firefighting, which would take away from the greater, the greater good. [Pro-VC Post-92 HEI]

Unease about compulsion is supported by empirical evidence from the US, where mandatory schemes are common especially in Liberal Arts institutions. If mandatory programmes are aligned to students' personal agendas, then they are more likely to be successful in nurturing young people's sense of civic responsibility, than compulsion without reference to students' requirements and expectations (Stukas et al, 1999). Masking the required component of mandatory volunteering and enhancing its sovereign capacity is more likely to bring about a positive evaluation. Moreover, the introduction of mandatory forms of volunteering could potentially have unintended consequences, in particular it would require support staff to manage students' placements and ensure that such volunteering opportunities were deployed effectively. Faced with these challenges the prevailing view among the stakeholders interviewed was that compulsion was inappropriate, rather students have to be educated about the opportunities to volunteer and associated benefits. Students themselves have to internalise the expectation of 
involvement and, reflecting Deleuze's observation, be self-motivated to engage with activities and through this engagement remake more fluid and democratic forms of power.

\section{Students' Engagement with Volunteering}

In many ways students' reaction to the institutional promotion of volunteering reflects the views expressed by stakeholders. However, this does not necessarily infer that institutions played a key role in facilitating students' participation. Rather in line with findings from existing research on engagement (Brodie et al, 2009), getting involved in volunteering was not necessarily a strategic decision. Participation was often a spur of the moment decision in response to an external trigger, this could be a request from a teacher or friend, or from seeing a notice in the student union, as Stella described:

And I first became involved, completely on a whim, I was wandering around the society sign up fair and saw it and just thought yeah, why not? [Stella: Volunteer]

Other students were more aware of their own personal reasons for volunteering and more explicit about the need to gain experience. Yet overall, echoing stakeholders' concerns that volunteering should not just be about employability, any personal motivation for volunteering is often balanced by a need to get volunteering 'right' (Holdsworth and Quinn, 2012). The importance of seemingly insignificant triggers and lack of strategic thinking behind young people's intentions does help to sustain the ideal of choice, that young people can chose to ignore the poster or request to get involved. Moreover if students have encountered more fixed and structured routes into volunteering, these are often resisted. As one student volunteer outlined the promotion of volunteering at his high school prior to 
coming to university was not only resented by students, but failed to actively engage his peers with volunteering:

[E]veryone had to have some sort of experience of volunteering, I think it was just like a tick, tick box sort of thing that they made students do. But a lot of people you know resented you know being 'forced' to do voluntary work ... We were actually, yeah, you know quite explicitly as like the reason for justifying volunteer work. So you know, yeah, if you volunteer you'll stand out more as a person to us and we'll be able to write more about you when it comes to university applications. [Wetherby: Volunteer]

While Wetherby resented being obliged to volunteer at school, he has been an active volunteer at university and uses his experiences as a student volunteer to critique the narrow focus of the teachers at his school, particularly the promotion of volunteering as a means to an end, in this case getting to university. Similar concerns were voiced by students with reference to volunteering at university. Both volunteers and non-volunteers were aware of the increasing expectation that volunteering was something that you did at university and that this expectation was closely bound up with the need to make yourself 'employable':

$[P]$ otentially because it kind of happened with university in a way, because it used to be if you had a university degree, it was a lot easier to get into jobs, but now it's kind of everyone has one really, and I think that will probably happen eventually that it's just expected of you, it will be the social norm that you have helped out with things. [Liam: Non-volunteer] 
Yet while students were aware of this expectation, this was not sufficient reason to encourage students to get involved. As Liam himself recognised, being told that volunteering is 'good thing to do' is not motivational, he is aware of why others might want to volunteer, but it is not important for him. Others students went further than this, criticising how students were expected to do 'even' more:

It's just like another thing for students that you know we have to do now isn't it? Work, work experience, volunteer, all these for the university. [Wetherby: Volunteer].

Thus while senior management at universities acknowledge that the promotion of volunteering is in response to external triggers, students resisted or at least contested these external pressures. Moreover while students were aware of the wider social imperative to volunteer, they were more dubious about the steps that universities were taking to encourage volunteering. In one of the focus groups with non-volunteers, the lack of information on volunteering was an important topic of conversation, as Liam summarised:

[S]eeing as it's kind of being pushed down our throats that you need to volunteer to get jobs, you need to do this, do that, it's not as well promoted as you'd expect it to be if they want you to get ahead of the game. [Liam: Non-volunteer].

There is a difficult balance here, on the one hand students resented being told what to do, yet also reported that more could be done to promote volunteering. Students will respond to hearing about volunteering opportunities. These can, as Stella described above, be relatively small initiatives and more directed towards raising the possibility of volunteering among students. Students also thought that academics had a role to play here, and that the 
space and time to talk about volunteering opportunities in lectures or seminars in a nonjudgemental manner could be a more effective way of stimulating students' interest than emphasising employability. Personalising the requirement to volunteer by appealing directly to students is a way of disguising the codification of volunteering and appealing to students' capacity for sovereign action.

Students' engagement in volunteering remains uneven. As the findings from the survey illustrate, though the majority of students report some form of participation (which can include helping out a friend or relative or involvement in a society), around a third of students do not, and the percentage who report formal volunteering (that is activity that is described as volunteering) is closer to one-fifth. Non-volunteers relate their reluctance to get involved with reference to lack of interest, rather than structural barriers associated with institutional practices or students' individual circumstances, such as employment or study commitments. For example, Chris suggests that apathy remains one of the main reasons that students do not volunteer:

I think students; I mean I think I could probably get a bit more involved to be honest. So yeah, obviously we could have a lot more like knowledge about it, but I think the students themselves need to change as well. I think they need to get out of bed earlier. [Chris: Non-volunteer].

Though Chris makes a joke about lazy students, apathy is a form of resistance that young people have used in the absence of more constructive ways of resisting authority, regardless of how power is distributed (Corrigan, 1993) and in the face of overwhelming reasons why students should volunteer, it is a justifiable defence. Thus the scripting of control onto 
students is not just creating docile bodies (Brooks, 2012), but for some resistance of this control is manifested by an almost torpid state.

\section{Discussion}

It would seem reasonable to concur with the observation made by one Pro-Vice-Chancellor that there are a lot of opportunities for volunteering at $\mathrm{HE}$, but how it is carried forward needs to be got 'right':

Right, I think volunteering's at a really exciting point now. I think what we've got to do is to manage this really carefully. We've got to ensure that we get the embedding right and the adoption of the sort of the whole issue around the development of the students embedded in the programmes. And what we've really then got to do is to make sure that the students take that very, very seriously, and that then that crosses over into the student volunteering. And I think it is about how we now handle this, because what we need to do is embed it and it becomes an accepted part. [Pro-VC Post-92 HEl].

As we have discussed, this measured optimism was articulated by both students and HE stakeholders. Yet the practices of embedding volunteering in HE activities, either within academic programmes or outside of these, has yet to be resolved. The incorporation of volunteering into mainstream university practice is not straight-forward. Neither students nor HE administrators supported coercion; so the challenge is to align students' expectations with institutional initiatives. The codification of volunteering is not achieved by compelling people to volunteer but through embedding the expectation that learning and skills are not just acquired through formal learning. The challenge for HE volunteering is to 
resist becoming a tick-box activity which would undermine the choices that students would like to make about getting involved. Thus while our analysis supports Baillie-Smith and Laurie's (2011) observation that volunteering is bounded by institutional practices and cultural norms; the option to choose, or at least have a say in what choices are provided, remains an essential quality of how volunteering is valued by young people. Students resent being told to volunteer, especially if this compulsion is tied to a specific aim, such as getting a job, but also recognise their responsibility to find out more about volunteering and act on their own initiative. Student volunteers appreciated the multifaceted aspects of volunteering, and the potential for it to add to their studies, as well as challenging their university experiences. A shared vision for volunteering is to remain a diverse and loosely defined activity in universities and one which students can access through a number of different routes in accordance with their varied needs and expectations. Making volunteering personal, while at the same time avoiding the pitfall of it appearing too instrumental and tied to individual advancement, would appear to resonate with the students in these case studies.

As with Ansell's (2008) study of gap-year volunteering, the consolidation of volunteering support in universities reviewed in this project falls short of total control of these activities. The ideal of volunteering as an individual vocation remains, though the paradox of institutional endorsement of distinctive activities that are meant to infer an advantage for individual students, has yet to be addressed. Students are aware that the capacity for volunteering to provide a unique expression of their personal capital (Brown et al, 2003) is reduced as volunteering is rolled out en masse. It is in this paradoxical endorsement of volunteering that the locus of control can be located. To return to Delueze, in control 
society discipline becomes embodied as institutional authority is dissipated. Students are not forced to volunteer, but have to accept that co-curricular activities are part of the remit of universities, and as such, subject to institutional monitoring. The logic of control society is that subjectivities are turned inside out. Young people are compelled how to be, rather than told what to do; they are exalted to live life to the full, which includes volunteering, though it is not possible for institutions, such as universities, to force young people to act in this way. Young people have to incorporate this expectation that they can articulate who they are and the skills and attributes that they have acquired through activities such as volunteering. At the same time universities have to respond to this transformation of students' alignment with institutions. In this study the six HEls recruited to take part as case studies, all supported some form of volunteering and the stakeholders who we spoke to were supportive of their institution promoting volunteering, yet institutional support is patchy across the sector.

Yet as volunteering, along with other co-curricular activities, is incorporated into the 'student experience', this raises the question of the capacity for student choice, which is identified as the main calibrator of the HE market. On the one hand the logic of neoliberalism espouses the importance of choice and freedom, yet in practice, as many students are aware, the outcome of not choosing to get involved could reduce their options on graduating. Students' capacity for deliberate choice about volunteering is restricted as the outcomes of engagement cannot be certain. This analysis concurs with Woodman's reinterpretation of Beck's individualisation thesis in which he argues that the unravelling of individualisation is not that young people have more choice, but that as 'some of the constraints placed on people are breaking down, the predictability and security that would allow these new options to function as choices to be deliberatively chosen also weaken' 
(2009: 254). We are looking therefore at a new way of interpreting the structure/agency debate that does not assume that the capacity for agency is enhanced as structures weaken or become more opaque. As the certainties of HE are contested, a 'degree is no longer enough anymore', young people are charged with the responsibility of navigating their own pathways, but without any certainty of the outcomes of their individual 'choices'.

As volunteering becomes a badge of distinction, as well, or even instead of, a commitment to community cohesion and social justice, it can be aligned with the desire and will for sovereignty, and the need to resist forms of codification (Lippens, 2012). Yet rather than fostering the creative capacity to get involved and really make a difference, the alignment of volunteering with entry into the graduate labour market, has the potential to stimulate suspicion and precaution. As young people interviewed in the study revealed, among both volunteers and non-volunteers, resistance to the compulsion to get involved with the 'whole' university experience is manifested by apathy to the student experience project. The difficultly of promoting volunteering is that this could potentially be destructive for what is trying to be achieved. That is rather than encouraging young people to be socially literate and aware of their own capacity to make a difference, the indoctrination of young people to a form of control through the expectation that they have to engage as part of institutional and political expectations, could bring about less ambitious forms of engagement. To return to the observation of the need to carefully manage volunteering, this depends on the principals underpinning the need for management. Aligning students' expectations with institutional ambitions mitigates the capacity for sovereign action and choice, while at the same time does not necessarily foster a commitment to civic action. As 
students we spoke to suggested, they want volunteering to be recognised and endorsed as a rewarding activity, but in a way that their agency is privileged and their capacity to make a difference is upheld. 


\section{Bibliography}

Annette, J. (2005), 'Character, civic renewal and service learning for democratic citizenship in higher education', British Journal of Educational Studies, 53 (3), 326-340.

Ansell, N. (2008) Third World gap year projects: youth transitions and the mediation of risk Environment and Planning D: Society and Space, 26(2), 218-240.

Baillie Smith, M. and Laurie, N. (2011) International Volunteering and Development: Global Citizenship and Neoliberal Professionalisation Today Transactions of the Institute for British Geographers 36 (4), 545-559.

Boyer, E. (1990), Scholarship Reconsidered: Priorities of the Professoriate, New Jersey: Princeton University Press.

Brewis, G. (2010) From Service to Action?: Students, Volunteering and Community Action in Mid Twentieth-century Britain, British Journal of Educational Studies 58 (4): 439-449.

Brewis, G., Russell, J. and Holdsworth, C. (2010) Bursting the Bubble: Students, Volunteering and the CommunityFull Report. Bristol: National Coordinating Centre for Public Engagement

Brodie, E.,Cowling, E. and Nissen, N. (2009), Understanding participation: A literature review, London: NCVO.

Brooks, R. (2012): The social construction of young people within education policy: evidence from the UK's Coalition government, Journal of Youth Studies, Brown, P., Hesketh, A. and Williams, S. (2003), 'Employability in a knowledge-driven economy', Journal of Education and Work, 16 (2), 107-126. 
Brown, P., Lauder, H. and Ashton, D. (2010) The Global Auction: The Broken Promises of Education, Jobs and Rewards, Oxford: Oxford University Press.

Cabinet Office (2010), Building the Big Society, available at:

http://www.cabinetoffice.gov.uk/news/building-big-society. Accessed September 201.

Corrigan, P. (2006) 'Doing Nothing' in S. Hall and T. Jeffersen (eds) Resistance through Ritual: Youth subcultures in Post-War Britain, London: Routledge, pp. 84-87. (First published 1975).

Collini, S. (2012) What Are Universities For? London: Penguin.

Darwen, J., \& Rannard, A. (2011), 'Student volunteering in England: a critical moment', Journal of Education and Training, 53 (2/3), 177-189.

Deleuze, G. (1992) 'Postscript on the Societies of Control'. October 59 (Winter): 3-7.

Edwards, B., Mooney, L. and Hweald, C. (2001), 'Who is Being Served? The Impact of Student Volunteering on Local Community Organisations', Nonprofit and Voluntary Sector Quarterly, 30 (3), 444-461.

Eley, D. (2003), 'Perceptions of and reflections on volunteering: the impact of community service on citizenship in students', Voluntary Action, 5 (3), 27-45.

Fyfe, N. (2005), 'Making space for neo-communitarianism? The Third Sector, State, and Civil Society in the UK', Antipode, 37 (3), 536-557.

Foucault, M. (1979) Discipline and Punish: The Birth of the Prison. London: Penguin.

Glover, D., Law, S. and Youngman, A. (2002) 'Graduateness and Employability: student perceptions of the personal outcomes of university education', Research in Post-Compulsory Education, 7 (3), 293-306. 
Handy, F., Cnaan, R.A., Hustinx, L., Kang, C., Brudney, J.L.,Haski-Leventhal, D., Holmes, K., Meijs, L.C.P.M., Pessi, A-B., Ranade,, Yamauchi N. and Zrinscak, S. (2010), 'A Cross-Cultural Examination of Student Volunteering: Is It All About Résumé Building?', Nonprofit and Voluntary Sector Quarterly, 39 (3), 498-523.

Hardt, M. and Negri, A. (2000) Empire. Cambridge MA : Harvard University Press.

Haski-Leventhal, D. Meijs, L., and Hustinx, L. (2009) The Third-party Model: Enhancing Volunteering through Governments, Corporations and Educational Institutes Journal of Social Policy, 39 (1): 139-158.

HEFCE (no date), HEAR http://www.hefce.ac.uk/learning/diversity/achieve/ Accessed September 2011.

Holdsworth, C., and Quinn, J. (2012) 'The Epistemological Challenge of Higher Education Student Volunteering: 'Reproductive' or 'Deconstructive' Volunteering? Antipode 44 (2): 386-405.

Hustinx, L. (2001), 'Individualism and new styles of youth volunteering: An empirical exploration', Voluntary Action, 3 (2), 47-55.

Hustinx, L. and Lammertyn F. (2003), 'Collective and Reflexive Styles of Volunteering: A Sociological Modernization Perspective', Voluntas: International Journal of Voluntary and Nonprofit Organizations, 14 (2), 167-187.Hustinx, L., Handy, F., Cnaan, R.A., Brudney, J.L., Birgitta Pessi, A and Yamauchi, N. (2010), 'Social and Cultural Origins of Motivations to Volunteer: A Comparison of University Students in Six Countries', International Sociology, 25 (3), 349-382. 
Hwang, M., Grabb, E. and Curtis, J. (2005), 'Why Get Involved? Reasons for VoluntaryAssociation Activity among Americans and Canadians', Nonprofit and Voluntary Sector Quarterly, 34 (3), 387-403.

Jochum, V., Pratten, B. and Wilding, K. (2005), Civil renewal and active citizenship: a guide to the debate, London: NCVO.

Jones, A. (2011) Theorising international youth volunteering: training for global (corporate) work? Transactions of the Institute for British Geographers 36 (4), 530-544.

Kahne, J. and Westheimer, J. (2006) 'The limits of political efficacy: Educating Citizens for a Democratic Society' PSOnline: 289-296 Available at www.apsanet.org.

Kendall, J. (2003), The Voluntary Sector: Comparative Perspectives in the UK, London: Routledge.

Larner, W. (2009) 'Neoliberalisam, Mike Moore and the WTO’ Environment and Planning A $41(7), 1576-93$.

Lash, S. and Urry, J. (1994) Economies of Signs and Space London: Sage.

Lippens, R. (2012) ‘Control over Emergence: Images of Radical Sovereignty in Pollock, Rothko and Rebeyrolle' Human Studies: International Journal for Philosophy and SocialSciences, 35 (3), 351-364.

Marullo, S. and Edwards, B. (2000), 'From charity to justice the potential of universitycommunity collaboration for social change', American Behavioural Scientist, 43 (5), 895-912. Miller, D. (2000), 'Citizenship: what does it mean and why is it important?', in N. Pearce and J. Hallgarten (eds), Tomorrow's Citizens. Critical Debates in Citizenship and Education, London: Institute for Public Policy Research. 
Milligan, C., and Conradson, D. (Eds.). (2006), Landscapes of voluntarism: New spaces of health, welfare and governance, Bristol: Policy Press.

Mohan, J. (1994), 'Making a difference? Student volunteerism, service learning and higher education in the USA', Voluntas: International Journal of Voluntary and Nonprofit Organizations, 5 (3), 329-348.

Mohan, J. (2012) Geographical foundations of the Big Society Environment and Planning A 2012, 44 (5), 1121-1129.

Norman, J. (2010) The Big Society: The Anatomy of the New Politics Buckingham: University of Buckingham press.

Rehberg, W. (2005), 'Altruistic individualists: Motivations for international volunteering among young adults in Switzerland', Voluntas: International Journal of Voluntary and Nonprofit Organizations, 16 (2), 109-122.

Rice, G. (2011) The 'Browneing' of public higher education in England Transactions of the Institute for British Geographers 36 (3), 333-337.

Smith, M.J. (2010), 'From Big Government to Big Society: Changing the State-Society Balance', Parliamentary Affairs, 63 (4), 818-833.

Squirrell, G. (2009), Student volunteering: Background, policy and context for NCCPE student volunteering, Bristol: NCCPE.

Stukas, A.A., Snyder, M. and Clary, E.G. (1999), 'The Effects of "Mandatory Volunteerism" on Intentions to Volunteer', Psychological Science, 10 (1), 59-64.

Watson, C. (2010) 'Educational policy in Scotland: inclusion and the control society' Discourse: Studies in the Cultural Politics of Education 31 (1): 93-104. 
Woodman, D. (2009) 'The mysterious case of the pervasive choice biography: Ulrich Beck, structure/agency, and the middling state of theory in the sociology of youth', Journal of Youth Studies, 12 (3), 243-256

\section{Acknowledgements}

The data are taken from a project led by the Institute for Volunteering Research and funded by the National Coordinating Centre for Public Engagement (NCCPE). This research project formed part of the NCCPE's vinspired students programme, which was funded by vinspired, the national young volunteers service, in order to provide evidence of the benefits of volunteering for students, universities and communities. We would like to thank all the participants in the research, Jamie Darwen and David Owen at NCCPE and Matt Baillie-Smith for comments on earlier drafts. 